\title{
NEEDS ASSESSMENT ACTIVITY REPORT
}

Date Published

August 1994

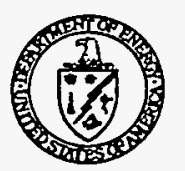




\section{RELEASE AUTHORIZATION}

\begin{tabular}{|ll}
\hline Document Number: & DOE/RL-94-106, Revision 0 \\
\hline Document Title: & Needs Assessment Activity Report \\
\hline Release Date: & $8 / 31 / 94$
\end{tabular}

This document was reviewed following the procedures described in WHC-CM-3-4 and is:

APPROVED FOR PUBLIC RELEASE

***************

WHC Information Release Administration Specialist:

Ghistivi Blillixgan

C. Willingham

$8 / 31 / 94$

(Signature)

$\frac{8 / 31 / 94}{\text { (Date) }}$




\section{DISCLAIMER}

This report was prepared as an account of work sponsored by an agency of the United States Government. Neither the United States Government nor any agency thereof, nor any of their employees, make any warranty, express or implied, or assumes any legal liability or responsibility for the accuracy, completeness, or usefulness of any information, apparatus, product, or process disclosed, or represents that its use would not infringe privately owned rights. Reference herein to any specific commercial product, process, or service by trade name, trademark, manufacturer, or otherwise does not necessarily constitute or imply its endorsement, recommendation, or favoring by the United States Government or any agency thereof. The views and opinions of authors expressed herein do not necessarily state or reflect those of the United States Government or any agency thereof. 


\section{DISCLAIMER}

Portions of this document may be illegible in electronic image products. Images are produced from the best available original document. 


\section{EXECUTIVE SUMMARY}

As part of a Transportation Management Division task (TMD), the Packaging Programs and Testing Group within Westinghouse Hanford Company (WHC) has assessed the packaging needs of some of the mid- and small-sized U.S. Department of Energy (DOE) sites by visiting them and meeting with their transportation and packaging personnel. To date, ten DOE facilities have been visited. As a result, these sites have been informed of some of the packaging activities that TMD has sponsored and is sponsoring, have been apprised of possible upcoming changes to transportation regulations, have discussed their short-term packaging needs, and have shared unique packaging they have developed which may be of use to other DOE facilities. Program successes include developing a questionnaire that discusses the potential impact of U.S. Department of Transportation (DOT) Docket HM-169A, Transportation Regulations; Compatibility with Regulations of the International Atomic Energy Agency; Notice of Proposed Rule (DOT 1989), discovery of a need for a reusable Type A liquid sample packaging and starting its development within another TMD task, coordinating resources between Fermi Laboratory and Argonne National Laboratory, and widening the distribution of WHC-EP-0558, Test and Evaluation Document for DOT Specification 7A Type A Packaging, (WHC 1994).

The future direction of this Needs Assessment activity includes continuing the strategy of visiting DOE sites to meet with their transportation and packaging personnel. The visits will continue to the smaller sites and visits to the larger DOE sites (e.g., Idaho National Engineering Laboratory, Savannah River) need to begin to ensure that all of DOE's needs are met and to determine whether any redundant packaging development is underway. . The site visits should be expanded to include 
meetings with the long-range and strategic planners at each site, and at the DOE-HQ level, to ensure that all future transportation and packaging needs are identified early enough to allow adequate transportation assessment and packaging development. This activity could become a permanent conduit for information and will ensure that all future DOE transportation and packaging needs are satisfied.

\section{REFERENCES}

WHC, 1994, Test and Evaluation Document for DOT Specification 7A Type A Packaging, WHC-EP-0558, Westinghouse Hanford Company, Richland, Washington.

D0T, 1989, Transportation Regulations; Compatibility with Regulations of the International Atomic Energy Agency; Notice of Proposed Rule; Docket HM-169A, U.S. Department of Transportation, Washington D.C. 


\section{CONTENTS}

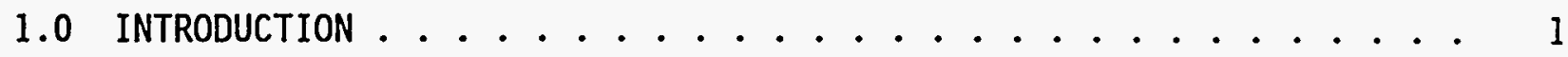

2.0 SITE PRESENTATION FORMAT . . . . . . . . ........ 1

3.0 SITE VISITS ..................... 2

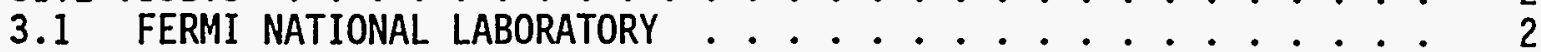

3.2 ARGONNE NATIONAL LABORATORY ................ 3

3.3 NEW BRUNSWICK LABORATORY ............... 3

3.4 EG\&G MOUND APPLIED TECHNOLOGIES ............ 4

3.5 FERNALD ENVIRONMENTAL MANAGEMENT PROJECT . . . . . . . 4

3.6 WEST VALLEY DEMONSTRATION PROJECT . . . . . . . . . 4

3.7 LAWRENCE BERKELEY LABORATORY .............. 5

3.8 STANFORD LINEAR ACCELERATOR CENTER . . . . . . . . . 5

3.9 BROOKHAVEN NATIONAL LABORATORY ............ 5

3.10 PRINCETON PLASMA PHYSICS LABORATORY ........... 6

4.0 REMAINDER OF FY 1994 ACTIVITY . . . . . . . . . . . . 7

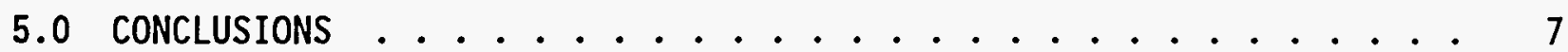

6.0 PROPOSED FUTURE ACTIVITY . . . . . . . . . . . . 8

7.0 REFERENCES ......................... 8 
DOE/RL-94-106

\section{LIST OF TERMS}

DOE

DOE-HQ

DOT

TMD

WHC
U.S. Department of Energy

U.S. Department of Energy - Headquarters

U.S. Department of Transportation

Transportation Management Division

Westinghouse Hanford Company 
DOE/RL-94-106

NEEDS - ASSESSMENT ACTIVITY REPORT

\subsection{INTRODUCTION}

The Packaging for Programs and Testing Group in the Transportation and Packaging Division of Westinghouse Hanford Company (WHC) started performing an assessment of the packaging needs for U.S. Department of Energy (DOE) in FY 1994. This assessment has been funded by the Transportation Management Division (TMD) Packaging Development Technical Task Plan, as the Packaging Projections subtask within the overall Performance Oriented Packaging task.

This activity originated as a result of several packaging development tasks initiated by the Packaging Programs and Testing Group in FY 1993. The introductory phase of those packaging development efforts typically included needs assessments that involved searching the DOE Complex for information of relevance to the specific task. During those searches it was found that a wide range of packaging and associated transportation needs had no formal mechanism for being addressed by DOE. Therefore, the Packaging Programs and Testing Group requested TMD to begin a task to investigate the different DOE programmatic packaging requirements and needs, evaluate the determined needs as compared to existing packaging resources, and evaluate the needs compared to potential TMD developmental efforts. TMD approved the Packaging Programs and Testing Group request, and work on the Needs Assessment began in FY 1994.

\subsection{SITE PRESENTATION FORMAT}

A questionnaire on U.S. Department of Transportation (DOT) Docket HM-169A, Transportation Regulations; Compatibility with Regulations of the International Atomic Energy Agency; Notice of Proposed RuTe (DOT 1989), and an agenda for the site visits was developed at the same time. DOT Docket HM-169A, if implemented in its original form, will have a major impact on DOE radioactive materials transportation by el iminating the use of strong, tight containers for most low specific activity shipments. It would instead require the use of packagings that have survived specific performance tests. DOT Docket HM-169A will also limit the radioactivity content of low specific activity shipments and introduce a new packaging category: surface contaminated object.

At the opening of each meeting, the role of TMD within DOE and its role in packaging development activities is discussed. Specific examples of packaging developed, or under development, within DOE -- such as special form neutron source packaging, Type A liquid sample packaging, and Type B Drums -are then presented. The presentation has evolved as new packaging that may have use throughout DOE are "discovered" or common needs are recognized. The questionnaire of DOT Docket HM-169A is then presented, and other ongoing regulatory activities including Performance Oriented Packaging are discussed. During these meetings, an active discussion between the presenters and the attendees is encouraged and usually occurs. After the presentations are 
complete, the sites are then asked to discuss any packaging needs they may have that are not being satisfied, and any packaging they may have developed which could be of use to other DOE facilities. Finally, any unique packaging or shipping facilities are visited.

The attendees at these meetings have, in general, been personnel in the packaging and transportation areas. Representatives from local DOE offices have either attended the meetings or have been visited separately after the meeting. The format of the meetings has been successful in gathering the most information possible from each DOE site.

\subsection{DOE SITE VISITS}

\subsection{FERMI NATIONAL LABORATORY}

The packaging needs and issues identified by Fermi included the following:

- Packaging for bulk radioactive materials (magnets), $2.5 \mathrm{ft} \times 2.5 \mathrm{ft}$ $\times 40 \mathrm{ft}$ and $3 \mathrm{ft} \times 3 \mathrm{ft} \times 45$ to $60 \mathrm{ft}$. They are considering possible use of Type A packaging, Tow specific activity-exclusive use closed transport (tarp and cage), or a multimodal container.

- Packaging for a Plutonium-Beryllium source that has no certified packaging currentiy available.

- Reusable Type A source packaging to support 100 to 200 shipments per year. They currently utilize one-time use Triple-wall fiberboard containers.

During this meeting the representatives from Fermi identified that they had not met with their transportation and packaging counterparts at Argonne National Laboratory, which is less than $20 \mathrm{mi}$ away. They attended the meeting with Argonne. The contact between these two facilities should improve both transportation and packaging programs.

\subsection{ARGONNE NATIONAL LABORATORY}

The packaging needs and issues identified at the meeting with Argonne were the following:

- Argonne has 140 tons of depleted uranium and lead that are available for use as shielding material for packaging. 
- No packaging is currently available for a $17,000 \mathrm{Ci}{ }^{60} \mathrm{Co}$ source destined for disposal as a result of Certificate of Compliance expirations. Argonne feels their alternatives include, obtaining an amendment to the T-3 safety analysis report for packaging, leasing a NuPac 10-142 cask, or leasing Chem-Nuclear Services 1-13 cask with insert.

- Packaging for ${ }^{90} \mathrm{Sr}$ and ${ }^{226} \mathrm{Ra}$ sources.

- Argonne intends to ship 1,000 $\mathrm{ft}^{3}$ of transuranics from decommissioning and disposal in 150 55-gal drums in the TRUPACT II container.

- Packaging for contaminated glovebox labware.

- Argonne needs to ship neutralized nitric acid contaminated with plutonium that is currently contained in 56 drums.

- Packaging for lead waste which requires 18 in. tall containers, preferably square drums.

- Packaging for highly tritiated water in a 55-gal drum. Argonne intends to use the Princeton Plasma Physics Laboratory molecular sieve.

- Packaging for a $72,000 \mathrm{lb}$ carbon stee 1 reactor vesse $1(120,000 \mathrm{lb}$ with 1 id and internal components). This reactor vessel has 20-50 mrem from activated metal surface contamination and is $28 \mathrm{ft} \times 7 \mathrm{ft}$ in diameter. They propose to cut the vessel into five sections and segment each section, possibly using plastic wrap and paint to affix surface contamination.

- Shipment of 1,000,000 1b of activated metal (e.g., magnets) that have no surface contamination. They may use plastic wrap to cover it.

- Packaging for waste generated from the decommissioning and disposal of the $40,000 \mathrm{~Tb}$ ZGS reactor.

\subsection{NEW BRUNSWICK LABORATORY}

The following issues and needs were identified at New Brunswick Laboratory:

- Requested a change in distribution for the Test and Evaluation Document for DOT Specification 7A Type A Packaging, WHC-EP-0558 (WHC 1994).

- A user-friendly Type A liquid packaging for use with routine shipments from gram quantities to kilogram size bulk standards by air, using both domestic, and international carriers. 
- New Brunswick expressed an interest in a Type A Tiquid packaging (one to two L capacity). This packaging must be compatible with acids (e.g., uranyl nitrate packaged in $50 \mathrm{~mL}$ ampules), provide multiple inner packaging, absorbent, and secondary containment. They presently use one "juice can" with multiple $50 \mathrm{~g}$ vials, and would like the ability to use two or three juice cans in one outer packaging.

- New Brunswick stated that the inability to certify packagings obtained for use by the Nuclear Regulatory Commission in the United States, despite International Atomic Energy Agency certification for use of those packagings, has resulted in serious logistical problems.

\subsection{EG\&G MOUND APPLIED TECHNOLOGIES}

Mound identified the following transportation and packaging needs:

- Two L Type A liquid packaging with glass or polyethylene inner packaging.

- Two L chilled liquid sample packaging.

- Explosives training modute.

\subsection{FERNALD ENVIRONMENTAL MANAGEMENT PROJECT} issues:

Fernald identified the following transportation and packaging needs and

- Requested a change in distribution for the WHC-EP-0558.

- Fernald expressed interest in a chilled sample cooler for radioactive and hazardous material in Packing Group II and III. They would require approximately $30 \mathrm{~L}$ in one package. Their present shipments are limited to five $L$. Their preferred packaging, fiberboard box with foam, DOT 33A or UN 4G, is no longer available as an assembled stock item from their vendor, and they must order as separate parts, which unnecessarily drives up costs.

- Packaging for large amounts of low-Tevel mixed waste.

- Packaging for 230 metric tons of depleted and enriched materials (i.e., $\mathrm{UF}_{4}$ and $\mathrm{UO}_{3}$ ).

- Packaging for many poison inhalation hazard cylinders, most of which contain chlorine. 


\subsection{WEST VALLEY DEMONSTRATION PROJECT}

The following packaging needs and issues were identified at West Valley:

- A misinterpretation of DOE Idaho Operations Office requirements had led West Valley to believe that the only acceptable Type A packaging were in WHC-EP-0558, and nothing else could be used. The Packaging Programs and Testing Group was able to clear up this misunderstanding.

- West Valley had difficulty obtaining 5-gal metal containers, DOT 6C and $17 \mathrm{C}$, in quantities of less than 600 . The Packaging Programs and Testing Group was able to solve their problem.

- West Valley had several questions about the impact of Performance Oriented Packaging regulations on the equivalency of DOT 17C or $17 \mathrm{H}$ drums to UN $1 \mathrm{~A} 2$ drums and the use of DOT $17 \mathrm{C}$ and $17 \mathrm{H}$ drums after 1996. The Packaging Programs and Testing Group was able to answer their questions.

- A reusable chilled liquid sample packaging is needed to ship organic samples to testing laboratories.

\subsection{LAWRENCE BERKELEY LABORATORY}

Packaging needs and issues identified by Lawrence Berkeley included:

- Packaging or suitable overpacks for storage, transportation, and subsequent disposal of tritiated water on a silica base (limited quantity/low specific activity/Type A) where hydrogen gas generation is a concern. Lawrence Berkeley has been in contact with Princeton Plasma Physics Laboratory about using their tritium shipping containers.

- Packaging or suitable overpacks for storage, transportation, and disposal of low specific activity tritiated mixed waste, where contamination of a tar substance used in the original package is a concern.

- Suitable packaging for a variety of sources.

- Request for additional distribution of WHC-EP-0558.

\subsection{STANFORD LINEAR ACCELERATOR CENTER}

Packaging needs and issues identified by Stanford included:

- A request for more information regarding the Radioactive Material Packaging database or other resources that may be accessed in order to $\mathrm{plan}$ Type B shipments and to select appropriate packaging. 
DOE/RL-94-106

- Packaging for numerous sources, including californium, cesium, and cobait.

\subsection{BROOKHAVEN NATIONAL LABORATORY}

The following packaging needs were identified by Brookhaven:

- Packaging for a 46,000 curie ${ }^{90} \mathrm{Sr}$ source that no other facilities want to reuse or dispose of and an approximately 30,000 curie ${ }^{60} \mathrm{Co}$ source.

- Shipping containers for plutonium-beryllium sources. These sources are currently located in storage containers that cannot be certified for transportation.

- Packaging for five chlorine and two tritium cylinders.

- Shipping and disposal containers for several large activated magnets that have some external rust. The external rust prevents, because of radiation exposure concerns, cutting these magnets into smaller pieces for shipment and disposal.

Brookhaven has developed a container that could be used throughout DOE for shipping and possibly disposal. Brookhaven has modified a multimodal container that is normally eight $\mathrm{ft}$ tall and developed two and four ft tall versions. The reduced height allows these containers to be completely filled and shipped on a legal weight truck. Unmodified multimodal containers require a large amount of void volume for shipment on legal weight trucks, which drives up disposal costs. However, followup discussions with Brookhaven personnel indicated that they would no longer use these multi-modal containers because they had found commercially available containers at half the cost.

\subsection{PRINCETON PLASMA PHYSICS LABORATORY}

The following packaging needs and issues were identified by Princeton:

- Princeton will be developing packaging for their present physics experiment, which will be activated metal in a torus shape with a maximum of 1,500 curies. Their current $p l a n$ is to cut the torus into five to ten pieces and develop Type A packaging for those pieces. They will also be developing Type A packaging for a neutral beam box.

- Princeton has a large amount of mildly-activated 304 stainless steel and 300 tons of slightly activated (with ${ }^{60} \mathrm{Co}$ ) copper that they want to recycle, instead of disposing.

- Potential need for low specific activity packaging for 5,000 gal of fluorinert (liquid teflon), if the fluorinert becomes radioactively contaminated in a future experiment. 
- Princeton requested that all shipping containers developed for large sources also meet applicable burial site acceptance criteria so that one design can be used for both functions.

Princeton has developed Type A and Type B packaging for tritium. Both packaging utilize a molecular sieve bed to capture tritium oxide vapor and then ship the molecular sieve bed. These packagings are available for use throughout the DOE Complex.

\subsection{REMAINDER OF FY 1994 ACTIVITY}

The Packaging Programs and Testing Group $\mathrm{p} 7$ ans to continue site visits with the same format over the remainder of FY 1994. These visits will be, in general, to 7 arger sites than have already been visited. Rocky Flats and the Waste Isolation Pilot Plant will be visited in Tate August or early September, and the Idaho National Engineering Laboratory will be visited in late September or early 0ctober.

\subsection{CONCLUSIONS}

The site visit format has been very effective to date. The sites visited have been cooperative and forthcoming with their packaging needs and developments. Visiting each site, in lieu of having one large meeting with attendees from each site, allows participation by site organizations not fully devoted to transportation and packaging. This increases the input from each site.

The most prevalent packaging needs within the DOE Complex, that have been discovered by the Needs Assessment include:

- Reusable Type A packaging for sources.

- User-friendly reusable Type A packaging for Tiquid samples.

- Chilled sample packaging that meets both Type $A$ and hazardous materials packaging requirements.

- Low specific activity or Type A packaging for large contaminated or activated objects (e.g., magnets).

- Radioactive materials packaging that can be used for both transportation and burial.

- Type B Packaging for high activity sources that currently do not have certified packaging because the certification of their existing packaging has expired. 
The Needs Assessment activity has found several packagings, including the Princeton-developed tritium packagings, that could be used throughout the DOE Complex. It has also initiated other important developments including the Type A laboratory sample packaging currently being developed by the Packaging Programs and Testing Group. The Needs Assessment has the potential to lead to many more packaging developments efforts by several different facilities with in the DOE Complex. Finally, the Needs Assessment activity has opened up communication pathways between various DOE sites that should help some of the smaller sites pool their resources and improve efficiency. This rewarding activity should help the DOE Complex, as a whole, become more efficient in transportation and packaging.

\subsection{PROPOSED FUTURE ACTIVITY}

The Packaging Programs and Testing Group proposes that the Needs Assessment activity continue for the foreseeable future with an expanded scope. To date, the sites visited have been smaller facilities with small transportation and packaging staffs. To ensure that their needs are met, the smaller sites should continue to be visited, because most smaller sites are unlikely to do much independent packaging development work. However, the larger sites also need to be visited. These sites are developing packaging of their own and, in many cases, have no knowledge of how that packaging could be used at other sites. This can lead to a duplication of effort by several sites. The visits to sites developing packaging would allow TMD to determine which sites have packagings that could be of use to other sites. TMD can also coordinate that development and ensure that the needs of a 71 sites are addressed. These TMD functions will make al1 DOE transportation and packaging activities more efficient and productive.

The Packaging Programs and Testing Group also recommends an expansion of the Needs Assessment activity to involve the long-range planners at each site and at U.S. Department of Energy - Headquarters (DOE-HQ). Presently, the visits have, in general, only included personnel aware of the immediate and short-term packaging needs at each site. Therefore, only the current and short-term packaging needs of each site have been included. Expanding the scope of the visits to include long-range planners at each site, and at the DOE-HQ level, would enable TMD to determine what the future packaging needs are. It would also prioritize development of those packagings, along with any technology required to support development, and ensure that the required packagings are available when needed.

Expanding the scope of the Needs Assessment activity would help TMD realize several strategic objectives. By becoming aware of all of the current and future transportation and packaging needs within DOE, TMD would be able to ensure that DOE can provide all capabilities required for transportation and packaging. TMD would also be able to provide centralized transportation management, create and utilize innovative technologies as necessary, and integrate transportation and packaging into all stages of DOE planning. Finally, the information gained from the expanded Needs Assessment activity would allow TMD to develop a method for prioritization of packaging and transportation development activities. 


\subsection{REFERENCES}

WHC, 1994, Test and Evaluation Document for DoT Specification 7A Type A Packaging, WHC-EP-0558, Westinghouse Hanford Company, Rich 1 and, Washington.

DOT, 1989, Transportation Regulations; Compatibility with Regulations of the International Atomic Energy Agency; Notice of Proposed Rule, Docket HM-169A, U.S. Department of Transportation, Washington D.C. 


\section{DISTRIBUTION}

Number of copies

OFFSITE

4

U.S. Department of Energy, Headquarters

656 Quince Orchard Road

Gaithersburg, Maryland 20878

G. P. Turi

L. G. B1alock

EM-26

E. B. McNeil

$E M-261$

EM-261

M. J. Conroy

EM-261

\section{ONSITE}

3

U.S. Department of Energy, Richland Operations Office

R. F. Guercia

R3-80

S. K. Moy

RL Public Reading Room

S7-55

H2-53

1

Pacific Northwest Laboratory

Technical Files

P8-55

47

Westinghouse Hanford Company

W. S. Edwards (40)

G2-02

T. M. Kaufman

G2-02

J. C. McCoy

G2-02

Correspondence Control

A3-01

Central Files

L8-04

Information Release

Administration (3)

L8-07 